$\mathrm{CO}_{2}$ レーザによる巨大な腹部腫瘍の手術

\title{
The Use of $\mathrm{CO}_{2}$ Laser in the Treatment of a Huge Abdominal Tumor
}

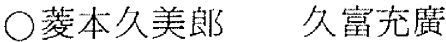

Kumio Hishimoto, M. D. and Mitsuhiro Hisatomi, M. D.

\author{
奈良春日病院 外科 \\ Department of Surgery, Nara-Kasuga Hospital, Nara, \\ Japan
}

\begin{abstract}
Among the 400 patients operated upon by use of the carbon dioxide laser surgical instrument through November, 1980 to August, 1984 , we have many cases in which the laser has been found definitely more advantageous than conventional surgical modalities. This report deals with our recent experience with rapid, lifesaving laser extippation of a huge abdominal tumor (leiomyoma weighing 4,500 grams) in a deteriorated 80 -year-old female.

In an introduction, statistical distribution, methodology and instrumentation of our laser surgical operations are summarized, and then, by showing a series of color slides, the usefulness of the laser in general surgery is demonstrated. A special emphasis is laid on the importance of training in laser surgical operations.
\end{abstract}

\section{1. 緒就}

$$
\text { わが国のレーザ医学は, 菱本 }{ }^{(1)} \text {, 桜井, 渥美ら }
$$

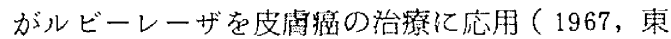
京大）したのが㜴矢である。レーザの外科的灾用 のなかでも，炭酸ガス $\left(\mathrm{CO}_{2}\right)$ レーザメスは代表的 存在であり，すぐれた機種が数多く利用できるに もかかわらず，一般外科の手術には未だ十分に活
用されていないのが現状である。

演者 ${ }^{(2)}$ は (6) , 早くから $\mathrm{CO}_{2}$ レーザ手術の基礎研究 に着手 ( 1969 ,シンシナチ大学)，1980年暮より 臨休応用に入り, 昨年までの迹例 362 (東京学災 病院）に本年夏までの症例 38 合算すると, 約 4 年間のレーザ手術数が 400 例に達する。とれは， 同期間に施行した手術総数のほぼ4割に相当する。 刘象藏器の内訳は (Fig.1), 皮有・軟部 156 例 
( $39 \%)$, 消化器 118 ( $29.5 \%)$, 乳腺 $47(11.8 \%)$, 䢸門 $30(7.8 \%)$, 甲状腺 $12(3 \%)$, リンパ節 10 ( $2.5 \%)$, 骨 - 腱 $9(2.3 \%)$, 性器 8( $2 \%)$, そ の他, 舌, 脾, 肺を含を $10(2.5 \%)$ などで, 心， 大血管, 中枢神経を除くはぼ全ての藏器にレーザ メスを適用したととになる。

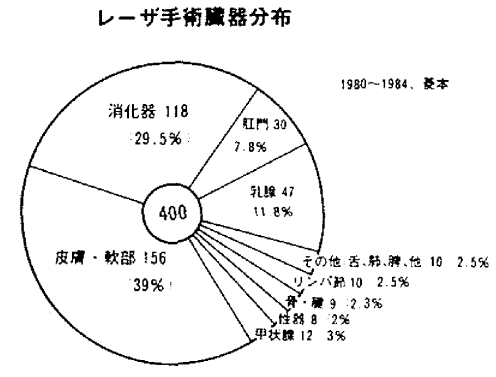

\section{Fig. 1 Organ distribution}

悪性腫瘍は 74 例 $(18.5 \%)$ で，胃癌 23 例，直腸

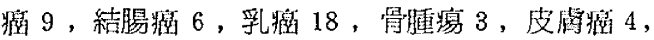

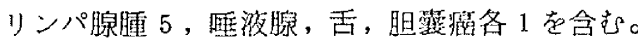

今回は，最近の手術から特に印乘的な症例を選 び，レーザ手術の過程を順次，写真で共覧しなが ら、レーザ外科の手技，コツなどを解説する。

\section{2. 症例}

80 歳, 女性。腹部膨満，呼吸困難，全身衰弱 を訴えて救急来院した。腹部に巨大な腫癔が存在 乙, 歩行不能。肺炎, 心不全, 尿路感染を合併し て重症のため，まず I CU に入院させて集中治療 で辛じて救命した。

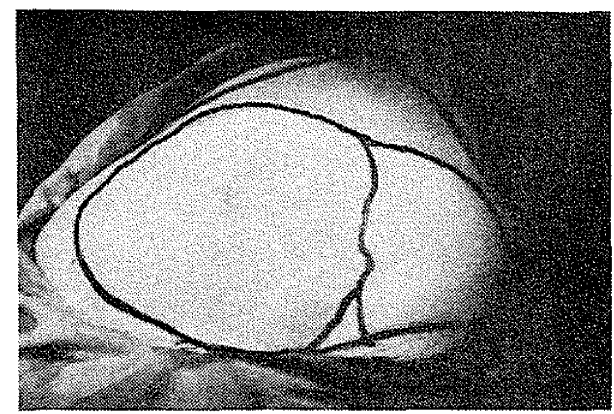

Fig. 2 A huge abdominal tumor
腹部腫嘴は，腹壁直下で腹部のほぼ全体を占拠 し(Fig. 2)，超成人頭大, 硬ないし弾性硬, 可 動性に乏しい。霄腸透視で，胃，十二指腸， S 状 結腸が上方へ，小腸締係が右上方へ顕著に圧排さ れている(Fig. 3)。尿路撮影では，腎，尿管に異 常を認めないが, 膀胱上縁に前下方への圧迫像が 存在する。超音波像，X線 CT 像（Fig.4）で， 中腹部後腹膜腔から骨盤腔まで広域に及ぶ巨大な 充実性婳痬が証明された。

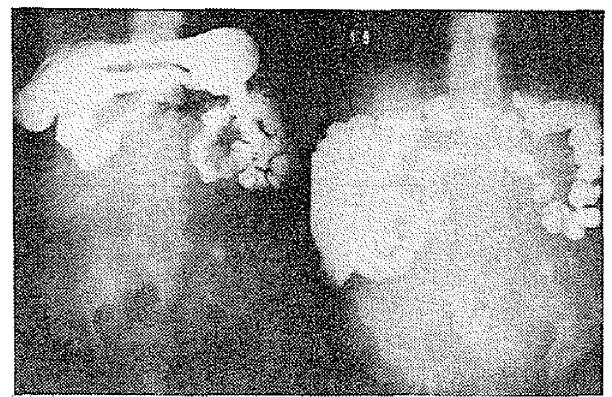

Fig. 3 Marked G. I. shifting

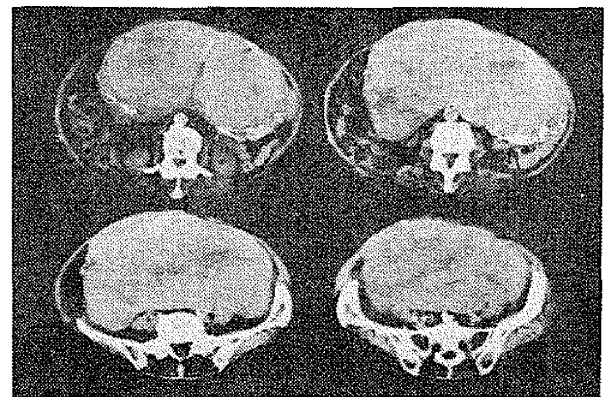

Fig. 4 X-ray CT

救急治療で救命後も腄痬の圧迫により，腹部緊 满, 呼吸困難, 呕気・呕吐, 便秘, 排尿困難が持 続ずるので, 全身状態の可及的改善を待って開腹 術を施行した。

3. レーザ装置

使用機種 4 は, アロカ L MC 352 型湠酸ガスレー ザ手術装蜀（Fig. 5 ）。T EMoo シングルモード, 単一パルス，並びに連続発振性のIRレーザメス で, 最大出力 $30 \mathrm{~W}$ 。集光レンズ $\mathrm{F} ： 50 \mathrm{~mm}$, 最小ス 
ポット经は $0.07 \sim 0.1 \mathrm{~mm}$ 。焦点切開のパワ一密度 は, スポッ卜经 $0.1 \mathrm{mn}$, 常用出力 $10 \sim 20 \mathrm{~W}$ 亿 対して $130 \sim 260 \mathrm{~kW} / \mathrm{ch̉。}$ 止血は主として, 非焦 点光の間歇照射で施行し, ビーム径 $5 \sim 8 \operatorname{m}$ とし 常用出力に対する平均パワ一密度 $20 \sim 100 \mathrm{~W} / \mathrm{ch}^{2}$ を計上した。

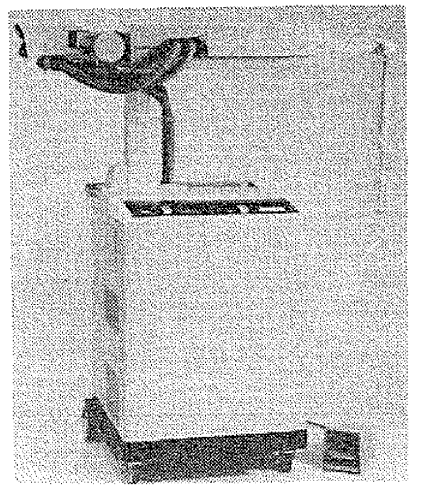

Fig. 5 The Aloka LNIC-352

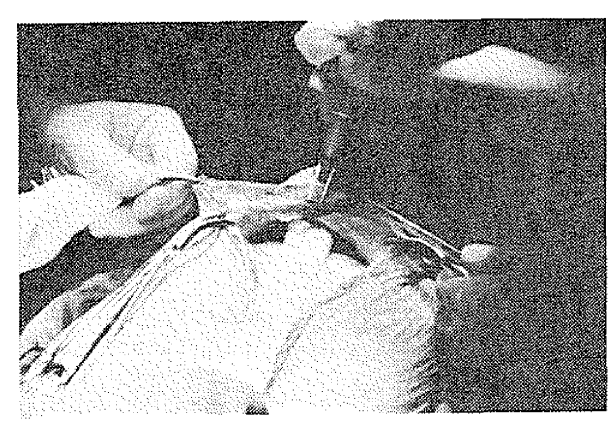

Fig. 6 Laser laparotomy

4. レーザ手術

全身麻酔下に, 皮切の一部を除いて手術の全過 程をレーザメスのみで完遂した。前方過照射を避 けるため，防蒣鈎を駆使した。剣状突起直下より 恥骨上部に至る正中切開で開腹 ( Fig.6,7), 出 血量は $12 \mathrm{~g}$ 。次に，腹腔内に突出する腫痬上で後 腹膜にレーザ切開を加え（Fig.8，9）, 主として 用手的に鈍性剝霍を進めた。レーザ照射で oozing

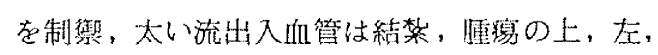
右極を後腹膜腔加ら遊雔した（Fig.10)。更に， 埂演塊を外下方へ脱転し，下極に連なる旁状物 （萎維した子宮体部）をレーザメスで切雊して， 腫堨を一箸に全剔した（Fig.11，12）。非焦点照
射の間歇反復あるいは連続走行により, 後腹膜腔, 骨盤腔内の出血点を焼灼, 凝固。ドレーンを留置 して後腹膜腔を縫合，閉鎖。腹壁は密に三層に縫 合, 閉腹した。手術時間は 2 時間 10 分, 術中総 出血量は $776 g$ 。

腫疲は巨大で, 最大经 $23 \times 23 \times 16 \mathrm{~cm}$, 重量 $4.5 \mathrm{~kg}$, 組織学的検查で浪良性の平滑笳腫で, 子 宮原発と考えられた。

後腹膜ドレーンは排液僅少で 3 日後に抜去, 抜 系は低栄養状態を考虑して, 術後 $10 \sim 14$ 日目に 施行した。術後に肺炎が再発した以外は経過順調 で体力回復後, 元気に退院した。

5. 結語

重症老人の超巨大な腹部蕾㾨の治療に当たり, $\mathrm{CO}_{2}$ レーザメスを巧みに駆使するてとによって，

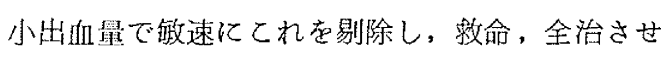
るととが出来たので，との症例をモデルにレーザ 手術手技の要点を紹介した。

\section{文 献}

（1）菱本久美郎・他：レーザビームによるヒト の腫焬の治療。臨外, 24:811 817, 1969

(2) Hishimoto, K., Rockwell, R. J. et al: Laser wound healing compared with other surgical modalities. Burns $1: 13 \sim 21$, 1974 (英国)

(3) 菱本久美郎 ·他: 外科領域における $\mathrm{CO}_{2}$ レーザ手術 360 例の経験と教訓。第 4 回日 本レーザ医学会総会抄録集P.76, 1983

(4) 菱本久美郎：レーザメス ( 外科 ME の最近 の進歩)。外科參寮, $26: 1277 \sim 1290$, 1984

（5）菱本久美郎：レーザメスによる消化器手術。 消化器セ之ナー，12：53〜 72, へるす出 版社 (東京), 1983

(6) Hishimoto, K.: Atlas of $\mathrm{CO}_{2}$ laser operations. Asian Med. J. 28(1) , 1985 (in press) (図次頁に) 


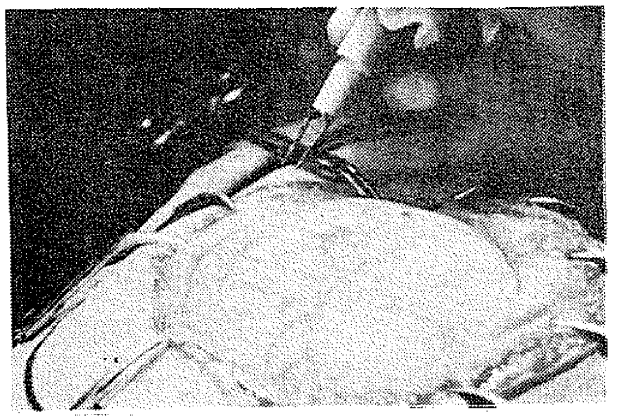

Fig. 7 Laser hemostasis

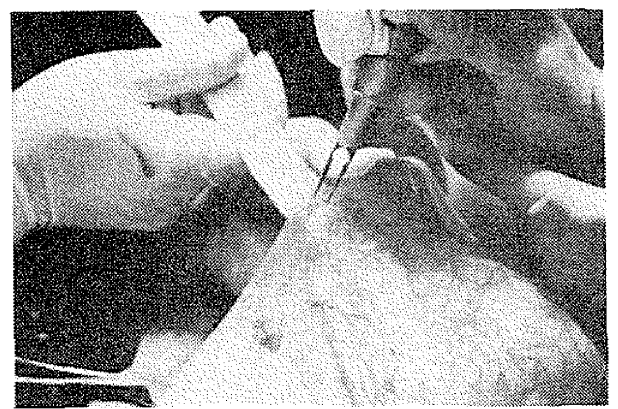

Fig. 8 Incise the retroperitoneum

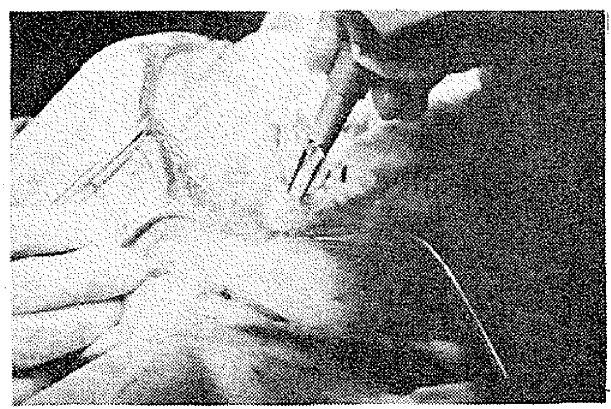

Fig. 9 Opening the capsule

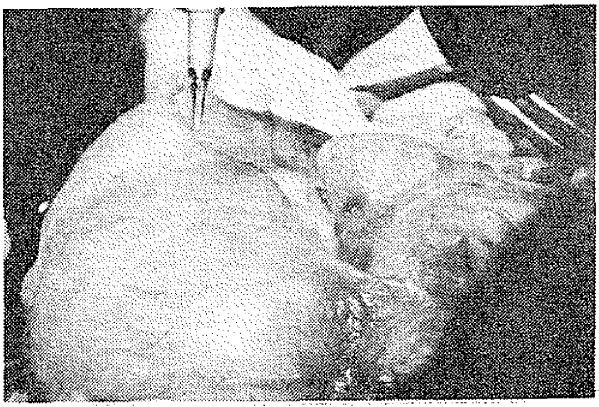

Fig. 10 The tumor pulled out

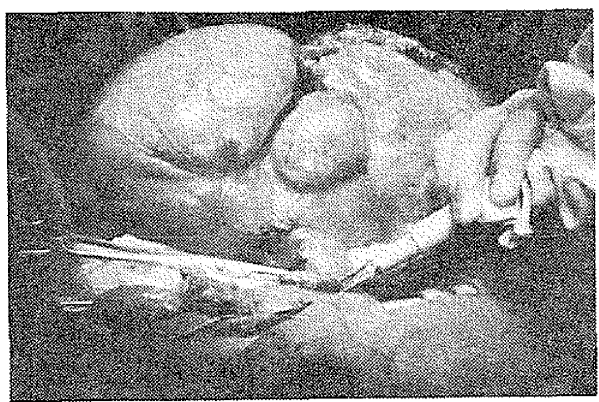

Fig. 11 Dissect the lower pole

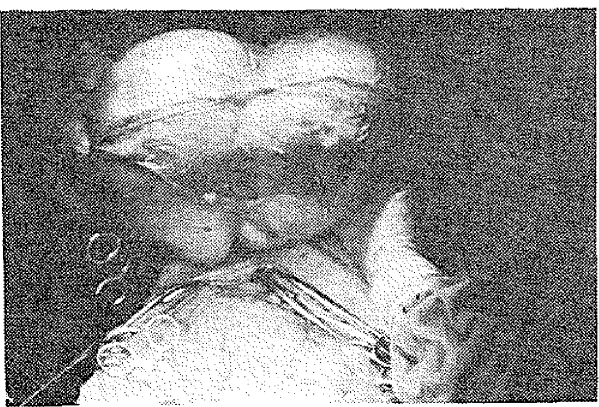

Fig. 12 The tumor extirpated

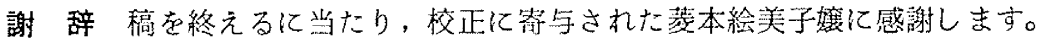

